eCommons@AKU

March 2018

\title{
Cough, Hemoptysis and Hair Expectoration: An Intrapulmonary Teratoma
}

Shanila Ahmed

Aga Khan University, shanila.ahmed@aku.edu

Habib Kibzai

Aga Khan University

Talha Shahzad

Aga Khan University, talha.shahzad@aku.edu

Saulat Fatimi

Aga Khan University, saulat.fatimi@aku.edu

Madiha Bilal l Qureshi

Aga Khan University

Follow this and additional works at: https://ecommons.aku.edu/

pakistan_fhs_mc_med_haematol_oncol

Part of the Hematology Commons, Internal Medicine Commons, Oncology Commons, and the Surgery Commons

\section{Recommended Citation}

Ahmed, S., Kibzai, H., Shahzad, T., Fatimi, S., 1 Qureshi, M. B. (2018). Cough, Hemoptysis and Hair Expectoration: An Intrapulmonary Teratoma. JCPSP: Journal of the College of Physicians and Surgeons--Pakistan., 28(3), 243-244.

Available at: https://ecommons.aku.edu/pakistan_fhs_mc_med_haematol_oncol/42 


\title{
Cough, Hemoptysis and Hair Expectoration: An Intrapulmonary Teratoma
}

\author{
Shanila Ahmed1, Habib Kibzai1, Talha Shahzad1, Saulat Hasnain Fatimi2 and Madiha Bilal Qureshi3
}

\begin{abstract}
Teratomas can be found in different organs of the body and may involve gonads, saccrococcygeal region, mediastinum and other sites. Intrathoracic teratomas always occur in mediastinum and less often arise within the lung. As teratomas mostly involve sex organs (gonads), they rarely occur as extra-gonadal tumors accounting for only $3 \%$ of all the cases and very small percentage of such tumors occur in mediastinum. We reported an interesting case of middle aged male who presented to us with symptoms of cough, hemoptysis and trichoptysis (hair expectoration). We found that patient had intrapulmonary teratoma that was initially being treated as case of pulmonary tuberculosis. He underwent surgical resection of his cavitatory lesion and diagnosis of intrapulmonary teratoma was confirmed by histopathology as well. The patient made remarkable recovery with complete disappearance of his symptoms. From Pakistan no such case has ever been reported. Although it is very unusual but in patient with cavitatory lesion, intrapulmonary teratoma should always be kept in mind as differential diagnosis.
\end{abstract}

Key Words: Intrapulmonary teratoma. Triochoptysis. Hemoptysis. Cavitatory lesion. Tuberculosis.

\section{INTRODUCTION}

Intrapulmonary teratomas (IPT) are extremely rare and so far less than fifty cases are reported in literature. These tumors arise from third pharyngeal pouch, which is endodermal in origin itself. 1 They are usually diagnosed in adult age and can occur in both man and woman. They are more often benign than malignant. Radiographically, they may present as irregular masses with calcification or entrapped air within them. Here we report an additional case of middle aged male admitted with history of hemoptysis and expectoration of hairs on coughing, which is a classic symptom - the telltale sign but is seen in $13 \%$ of cases. ${ }^{2}$

\section{CASE REPORT}

A 40-year gentleman, recently diagnosed with hypertension, had septoplasty and tonsillectomy in January 2016, presented to us with history of hemoptysis on/off for 6 years, expectoration of light brown thread-like material in sputum often for 2-3 years. He was investigated multiple times for his complaints, and antituberculosis treatment was also advised. He had no complaint of chest pain, weight loss and shortness of breath. History of tuberculosis and contact with animals was not significant. He was a non-smoker and had never been addicted to anything.

Department of Internal Medicine1 / Surgery ${ }^{2}$ / Pathology \& Laboratory Medicine ${ }^{3}$, The Aga Khan University and Hospital, Karachi.

Correspondence: Dr. Shanila Ahmed, Department of Internal Medicine, The Aga Khan University and Hospital, Karachi.

E-mail: shanilaahmed90@yahoo.com

Received: February 28, 2017; Accepted: August 04, 2017.
His physical examination and routine hematological labs were fairly unremarkable. On chest X-ray, there was a fibrotic band occupying left upper zone of left lung. His tuberculosis workup was negative. On CT-scan, there was intrapulmonary cavitatory lesion involving left upper end of lung having solid component and peripheral rim of air. Initially, he was misdiagnosed as case of aspergilloma. Therefore planned for surgery.

On thoracotomy, a firm irregular mass was found in anterior lobe of left lung. It was an isolated mass and had no connection with surrounding mediastinal structures. A standard anterior segmental resection was carried out. The postoperative course was uneventful. Gross section of the tumor showed cavitatory spaces, filled with sebaceous material containing tuft of hairs and a tooth.

Histopathology showed cystic lesion with ciliated columnar epithelium including lymphoid aggregates with prominent germinal center. Features were favoring the diagnosis of mature cystic teratoma.

\section{DISCUSSION}

Teratomas are the tumors that arise from pluripotent cells and belong to one of the class of germ cell tumors. The word 'teras' is a Greek word which means monster. These tumors arise from totipotent cells representing their origin from germ cell layers and most commonly occur as midline structure. Teratomas are germ cell tumors and most commonly present in sex organs and rarely involve other organs. A very small percentage of such extra-gonadal tumors found in mediastinum accounting for less than $2 \%$ of all the cases. ${ }^{2}$

Patients with intrapulmonary teratoma may have variable clinical manifestations, most common are chest 


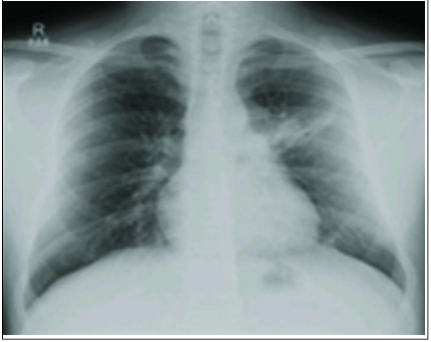

Figure 1(A): Chest $X$-ray showing infiltrates in upper zone of left lung.
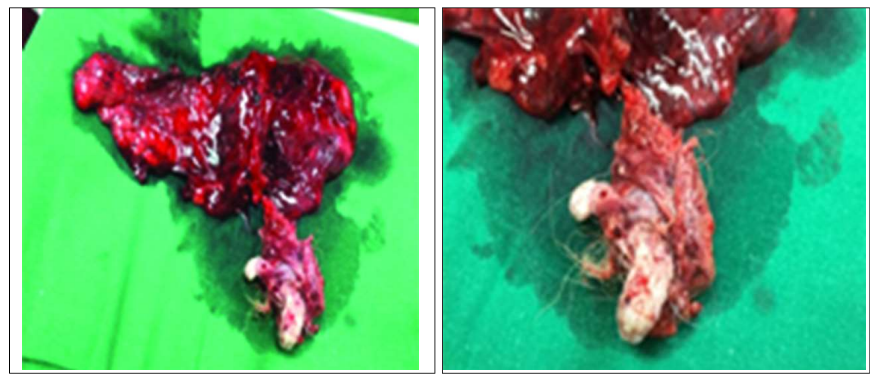

Figure 2(A,B): Gross appearance of IPT showing tooth and tuft of hairs.

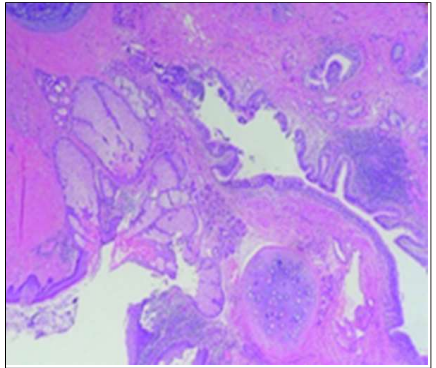

Figure 3(A): Section shows bronchial wall with pseudostratified columnarciliated lining, smooth muscle and cartilage. The underlying teratoma shows skin with adnexae.

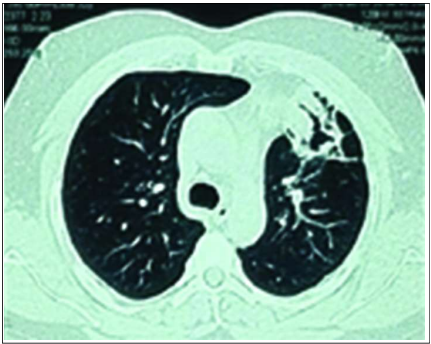

Figure 1(B): CT chest showing cavitatory lesion occupying upper zone of left lung.

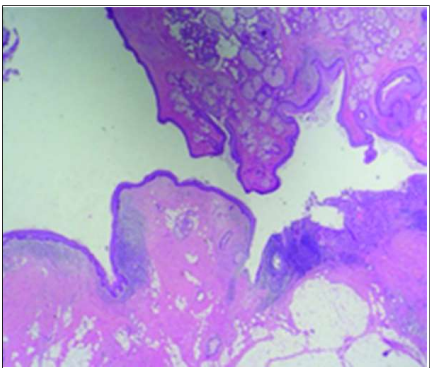

Figure 3(B): Section shows teratoma with components of skin with associated adnexae, seromucinous glands, lymphoid tissue, adipose tissue and cartilage. pain $(52 \%)$, blood in sputum $(42 \%)$, productive cough $(39 \%)$ and hair expectoration (13\%), which is the most specific and significant symptom. ${ }^{3}$ Bronchiectasis and post-obstructive pneumonia occur in $16 \%$ cases only, sometimes cause delay in diagnosis of lung lesions. Few patients may also present with pyothorax. Majority of intrapulmonary teratomas occur in the left upper lobe, whereas occurrence in right lung is less common. ${ }^{4}$

Teratomas can be benign as well as malignant. Benign ones are well differentiated and are known as mature teratomas; whereas, malignant ones are poorly differentiated and are known as immature teratomas. Most of them are benign and are encapsulated; and do not have potential for distant spread and because of this quality can be cured completely by surgical resection alone. 5

Histopathologically, it can manifest as various ectodermal, mesodermal and endodermal derivatives, and well differentiated structures from all three germ layers. Hairs, nails and teeth are most commonly found structures within these tumors, others include respiratory epithelium, pancreatic or gastric tissues, cartilages and muscles. 6,7

Operation related complications are the only significant cause of prolong hospital stay that are reported. Intrapulmonary germ cell tumors should be considered as differential diagnosis when investigating an intrapulmonary cavitatory lesion in adults; so that not to be treated mistakenly as pulmonary tuberculosis.

\section{REFERENCES}

1. Morgan DE, Sanders C, McElvein RB, Nath H, Alexander CB. Intrapulmonary teratoma: a case report and review of the literature. J Thorac Imaging 1992; 7:70-7.

2. Rajagopala Srinivas MD, Saxena AK. Triochoptysis due to an intrapulmonary teratoma. Respir Care 2007; 52:1779.

3. Saini ML, Krishnamurthy S, Kumar RV. Intrapulmonary mature teratoma. Diagn Pathol 2006; 1:38.

4. Day DW, Taylor SA. An intrapulmonary teratoma associated with thymic tissue. Thorax 1975; 30:582-7.

5. Allan JS. Rare solitary benign tumors of the lung. Semin Thorac Cardiovasc Surg Pediatr Card Surg 2003; 15:315-22.

6. Khan JA, Aslam F, Fatimi SH, Ahmed R. Cough, fever and a cavitatory lung lesion - An intrapulmonary teratoma. J Postgrad Med 2005; 51:330.

7. Macht M, Mitchell JD, Cool C, Lynch DA, Babu A, Schwarz MI. A 31-year-old woman with hemoptysis and an intrathoracic mass. Chest J 2010; 138:213-9. 